\title{
Creative Chinese Countryside? Township-Village Enterprises as Incubators
}

\author{
Mengchuan Liu ${ }^{\mathrm{a}}$, Yi-Wen Wang ${ }^{\mathrm{b} *}$, and Christian Nolf ${ }^{\mathrm{b}}$ \\ a School of Environmental Science, University of Liverpool, Liverpool, United Kingdom \\ $b$ Department of Urban Planning and Design, Xi'an Jiaotong Liverpool University, Suzhou, China \\ *Corresponding author: yiwen.wang@xjtlu.edu.cn
}

\begin{abstract}
Since the turn of the century, creative industries have displayed considerable power in transforming the social and economic landscapes of most global metropolises, including such Chinese mega-cities as Beijing and Shanghai. However, the story of creative industries does not end there. Recent studies have focused on the role of creative sector in the countryside. It has been argued that the creative sector can effectively contribute to diversifying socio-economic development in rural areas by increasing employment, enhancing the quality of life, and promoting social inclusion and community development. With the aim to chart new paths for China's rural revitalisation and address the country's 'three rural issues' (i.e. agriculture, rural areas and farmers), this paper examines the potentials and challenges to developing the creative sector in rural China. It first reviews the academic debate about expanding the development of creative industries from urban to rural areas. Drawing on the research and classification of creative industries in rural Western Ireland, this study identifies industries characterised by 'content creation and production' and 'creative design services', which would have potential in rural China. The major impediments to and crucial factors for developing rural creative industries in China are investigated and appraised within the framework of 'creative people, creative place, and creative support'. After analysing emerging practices in Jiangsu Province, this paper highlights the potential of abandoned industrial complexes in rural parts of China's coastal regions, which can act as incubators for creative industries. Those former manufacturing plants are the remains of township-village enterprises (TVEs), which constituted part of China's flagship policy for rural regeneration in the 1980s. Not only do they have special architectural attributes favourable for creative production, but also represent the socio-economic entity of the village collective and are the carriers of cultural meanings and memories. This paper concludes with a set of recommendations for both public and private sectors. It calls for a more proactive stance from governments to promote the creative sector in rural areas and revitalise rural economies and communities through the reuse or regeneration of former TVEs.
\end{abstract}

KEYWORDS cultural and creative industries; China; rural revitalisation; township-village enterprises (TVEs); adaptive reuse; industrial heritage

Received July 23, 2019; accepted December 9, 2019.

\section{Introduction}

Since the turn of the century, creative industries have begun appearing as clusters and agglomerations in China's major cities, such as Beijing, Shanghai, Guangzhou, and Shenzhen. The creative economy has been vigorously promoted in those cities-often within designated 'creative industry parks' to receive preferential policy support (Xiang and Walker 2013; O'Connor and Gu 2014; Gu 2011; Kong and O'Connor 2009; Zhong 2010). With their political, cultural, and economic significance, creative industries have entered mainstream discourse, and the city governments' conceptualisation of cultural policies is closely connected with maximising the economic yield of such industries (White and Xu 2012; Wang 2003; Zhang 2006).

What has taken place in China is just a small part of a much broader global trend. Over the past two decades, the rise of creative economies has been observed worldwide and has attracted considerable attention. Moreover, 
having proven resilient to the global economic recession, creative economies are nowadays considered a catalyst for socio-economic development by both city governors and policy makers. There is a commonly held assumption that embracing creativity can generate higher revenue, provide more employment opportunities, and strengthen social stability for businesses, organisations, and the local economy (OECD 2014; White 2010; Oyekunle and Sirayi 2018). Scholars have regarded creativity as the key characteristic that distinguishes $21^{\text {st }}$-century economies, just as those of the $19^{\text {th }}$ and early $20^{\text {th }}$ centuries were typified by manufacturing. The notion of a 'creative city' (Landry and Bianchini 1995; Landry 2008) and the theorisation of a 'creative class' (Florida 2005) have gained considerable prevalence and political momentum.

While governments at all levels have placed the creative economy high on the policy agenda of national, regional, or local development strategies (Gibson 2014b), this approach to the creativity economy has been questioned and challenged by scholars. Criticisms range from the overly urban focus (which fails to explain the creative industries and cultural activities that have grown in parallel in rural areas) to their limited applicability to rural planning and on a regional scale (Sorensen 2008; Bell and Jayne 2010; McGranahan and Wojan 2007; Gibson 2014a). Doubts have also arisen over the measurement of the creative class and economy that consider some occupational professions that obviously require little creativity. There is also a lack of statistical evidence derived from a multivariate analytical framework to prove a direct correlation between the creative class and economic growth (McGranahan and Wojan 2007). The adverse consequence of enacting policies favouring creative industries has also been highlighted; in particular, that includes the role of the government in gentrifying core urban areas, catering for the interests of elite groups, and perpetuating socio-economic inequalities (Markusen 2014; Balfour, Fortunato, and Alter 2018).

Although numerous studies on creative industries have been conducted, few have investigated creative activities taking place and thriving outside towns and cities. There have been many high-profile cases of creative industries in cities, ranging from Nashville, Los Angeles, Barcelona to Brisbane; dealing with such industries as film, music, television, and design (Gibson 2014a). However, an untold part of the story is that the countryside also has considerable potential for developing a creative sector, and the creativity of rural regions remains untapped and yet to be discovered (Collins and Cunningham 2017). Recasting
Florida's measurement of the creative class by excluding low-creativity occupations, McGranahan and Wojan (2007) analysed rural counties in the United States and found a strong correlation between the presence of the creative class and rural growth. It has been argued that developing the creative sector in the countryside may help cope with existing rural issues and reduce urban-rural disparity. For instance, in Australia, the physical distances of the country's interior are great; the geographical distribution of wealth is uneven; and the urban hierarchy is polarised-a few large cities on the coast and many small towns scattered across the country (Gibson 2014b). Developing creative industries is thus regarded as a positive approach to deal with these issues and relieve a national economic problem: Australia's 'tyranny of distance' (Battersby and Ewing 2005; Gibson 2014a).

Urban-rural disparity has been highlighted in recent policy directives of China's state government. Since the economic reform and open door policy in 1978, the enthusiasm for building big cities has swept across the country, and the consequence of this rapid urbanisation is the severe 'three rural issues' (agriculture, rural areas, and rural people). Limited employment opportunities, low agricultural income, and poor environment and infrastructure in rural China oblige more and more farmers into migrating to cities, seeking jobs and betterment. Out-migration results in 'hollowed-out' villages, which experience a decline in population and ageing problems; this further aggravates the economic and social atrophy in the countryside (Gaetano and Jacka 2004; Verdini, Wang, and Zhang 2016). Wistful nostalgia for attractive countryside that was evoked and campaigned by China's national leader accentuates the need for government policies to address the three rural issues (Xi 2013).

In recent years, several national initiatives and policies have been launched for rural regeneration in China. They include the nationwide campaigns for Beautiful Countryside in 2013, Characteristic Towns in 2016, and Pastoral Complex in 2017 and, more recently, the launch of Strategic Planning for Rural Revitalisation in 2018. From these, we can discern a pronounced shift in policy focus on rural regeneration, which now goes beyond agricultural moderation and physical environment improvement, and has expanded further to prompt an integrative development of primary, secondary and tertiary industries. Specifically, policy intentions have shifted from improving the living environment in the countryside, to revitalising rural regions from the various perspectives of industries, talent, culture, ecology, and organisation in 
the new era of 'rural revitalisation'. The implementation of other policies to increase financial support, reform the rural land system, and encourage collaboration between government and social enterprises is also aimed to diversify rural industries and enhance urban-rural integration. Although a specific policy addressing the development of creative sectors in rural China has not yet been introduced, it has been repeatedly cited in recent policies on rural regeneration. Launching state-led campaigns for developing the creative sector in rural regions may be just a matter of time; potentially, it is an effective approach for addressing the three rural issues.

While rural regeneration has been accorded high priority on the government agenda, it is evident that some creative and cultural industries have begun settling and thriving in China's countryside, though on a relatively small scale compared with urban areas. The phenomenon of reinventing abandoned sites of rural factories for creative reuse has recently been observed ( $\mathrm{Xu}$ and Aoki 2018). Such movement of artists into old industrial districts is not new and was notably witnessed in Beijing and Shanghai in the late 1990s, which was before Florida (2005) coined the term 'creative class'. Examples include the 798 in Beijing and M50 in Shanghai, both of which were converted from derelict factory buildings, attracting artists and start-ups to set up studios and offices there for the industrial aesthetics of the buildings, high-ceilinged and spacious rooms, and an affordable rent with a central location (O'Connor and Gu 2014; Hee et al. 2008; Zhong 2009; Gu 2011; Kong and O'Connor 2009; Zhong 2010). However, the Chinese approach to creative industry development has been characterised by the designation of specific 'creative industry parks', only within which can creative workers and start-ups receive benefit from preferential policy support. This approach is feasible only in metropolitan cities and has been much criticised (O'Connor and Gu 2014). The rise of creative industries in rural factories has stirred debate about the possibility of creative industries developing in China's non-metropolitan areas.

Most of those abandoned industrial buildings and sites are former township-village enterprises (TVEs) - China's preferential policy in the 1980s, aiming to diversify economic activities and increase the income of rural communities, mostly by means of introducing manufacturing to the countryside. After years of abandonment, those rundown industrial structures caught the attention of a small number of companies, organisations, and individuals who initiated projects to introduce creative industries to different rural areas in China. Examples include: the Design for County initiative, which was commissioned by the Shanghai Municipality and undertaken by a local firm (MOMA Design Company), setting up industrial design training centres in Rizhao, Ma'anshan, and Anshun; the Zhujiadian Brick Kiln Museum in Kunshan, which was transformed from an abandoned brick kiln; and Sanniaocang ('Three Birds Factory') Art Space in Nanjing (Figure 1 ), which was converted from an under-used gypsum factory (MOMA 2019; Cui 2018). The reasons for implementing these projects are various, ranging from generating profits to artistic pursuits. Most of those projects are financed privately or jointly by communities. The entrepreneurial and collective endeavours of local communities, however, have appeared to be incapable of generating sufficient economic returns to sustain the projects.

This paper examines the potentials and challenges in developing the creative sector in rural areas of China. Given the circumstances that China is currently facing, the key question this research seeks to address is how to introduce and develop creative industries in the countryside through repurposing abandoned factories. Drawing on the literature, policy reviews, and field visits, this study explores the transferability of urban-centric creative industries to rural locations by reviewing the current discourse and debate on the topic. Suitable creative categories for rural China are then discussed and identified by comparing the classifications of creative industries in Ireland and China. The three-pillar framework of 'creative people, creative place, and creative support' proposed by the Western Development Commission of Ireland for developing the creative sector in rural areas is employed to examine issues and supporting factors for developing rural creative sectors in China. To explore the potential role of TVE reuse in China's recent national initiatives and campaigns for rural regeneration, two precedent cases: Sanniaocang Art Space (Nanjing) and Zhujiadian Brick Kiln Museum (Kunshan) are examined to determine the motivations of creative entrepreneurs in relocating to the countryside and the challenges they have faced. The two cases also verify the findings related to suitable creative categories for rural China. Finally, a key contribution of this paper is offering a set of preliminary recommendations to both the public and private sectors, calling for policy support and a more proactive stance from governments to support relevant stakeholders in working collaboratively and making rural China 'creative'. 

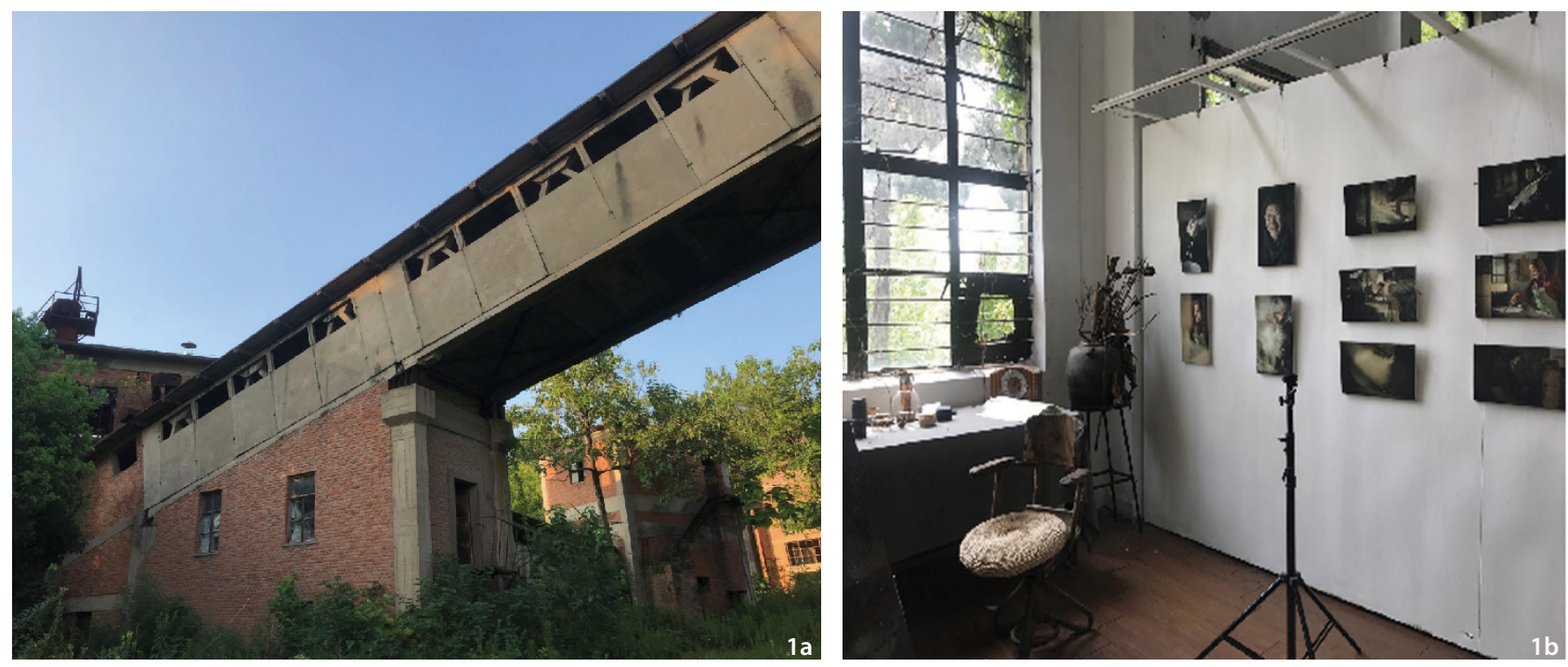

Figure 1a and 1b From an abandoned gypsum factory to an art space (Source: Mengchuan Liu).

\section{Creative Industries: Transferable from Urban to Rural Areas?}

To understand the transferability of creative industries from urban to rural regions, it is essential to return to the origins of creative industries in general. The concept of cultural and creative industries first emerged in the 1990s, when several European countries began to observe the economic value embedded in cultural production. A widely accepted definition of creative industries is 'those industries which have their origin in individual creativity, skill and talent and which have a potential for wealth and job creation through the generation and exploitation of intellectual property' (DCMS 2001, 44). In some disciplinary or cultural contexts, creative industries may be referred as the creative economy (Howkins 2002) or cultural industry (Hesmondhalgh 2013). Since then, creative industries have been considered an increasingly important component for enhancing economic well-being. Proponents of creative industries predicted that the industries of the $21^{\text {st }}$ century would depend increasingly on creativity and innovation (Landry and Bianchini 1995) and argued that human creativity would generate ultimate economic resource (Florida 2002).

Under the shadow of the global economic recession since 2008, the development of traditional industries, such as agriculture and manufacturing, has decelerated or declined. In contrast, creative industries have maintained a relatively higher growth rate over recent years (White 2010). For instance, in the United Kingdom, creative industries generated $£ 91.8$ billion in 2016, representing yearon-year growth of $7.6 \%$, compared with $3.5 \%$ for the UK economy as a whole (Rosenzweig et al. 2018). Studies have also shown that creative industries are closely associated with skilled employment (e.g. $46.8 \%$ of creative workers in the European Union in 2004 had at least a university degree), which in turn spurs and stimulates innovation in other sectors, enhances social inclusion, and fosters community development (WDC 2009; KEA European Affairs 2006; NESTA 2006). The value of creative industries in urban areas has been extensively researched and widely recognised; however, little attention has been paid to creative industries starting up in rural areas. This section provides a glimpse into the recent debate on creative industries in terms of their locational choices between urban and rural regions. It then examines different classifications of creative industries proposed in the United Kingdom, Ireland, and China in order to identify the types of creative industries that favour rural locations and settings.

\section{Debate on Location: Creative Industries in Peripheral Regions}

Over the past two decades, the profound impact of creativity on socio-economic development has been widely recognised by many countries. It is irrefutable that creative industries stimulate the development and regeneration of cities. However, the urban bias of the creative industry discourse that creeps in both scholarly publications and policy objectives has to some extent suppressed the imaginations of promoting creativity in the countryside. In The Country and the City, Raymond Williams (1975) duly notes that rural areas have been described as backward, limited, and ignorant, whereas urban areas are closely bound up with learning, innovation, and creativity. This 
deeply entrenched concept of aligning creativity with the city implies the lack of creative production in the countryside (Collins and Cunningham 2017). Creativity is by no means exclusive to the city; in fact, the countryside also has abundant creativity.

Recently, a small body of literature has appeared and focused on creative economies in more rural, peripheral, and remote regions, including Creative Economies in Peripheral Regions by Patrick Collins and James A. Cunningham (2017) and Creativity in Peripheral Places: Redefining the Creative Industries, edited by Chris Gibson (2014). Some of these pioneering studies explore the business development model of creative industries in peripheral regions; other studies identify rural features and factors that attract and nurture creative economies. Further research examines creative production taking place in various places outside big cities towards an expanded, inclusive redefinition of creative industries in a broad sense (Gibson 2014a, b; Collins and Cunningham 2017). Meanwhile, some government documents and reports also show that in recent years, more countries have regarded the development of rural creative industries as a vehicle for rural revitalisation. For example, Creative West: The Creative Sector in the Western Region, published by the Western Development Commission of Ireland (WDC 2009), proposes broad nationwide recommendations on stimulating rural creative sectors based on regional circumstances. All these studies call for recognition for the existence and increasing interests in rural creative industries.

The special locational advantages of rural areas can attract creative workers. Studies have shown that for some particular types of creative industries (especially those classified as 'creative expressions'), remoteness and rural landscapes can stimulate creativity and inspiration. For example, remoteness secures the authenticity of indigenous art and music, which is often required to successfully market products (Myers 2002; Gibson and Connell 2004; Christen 2006; White 2010). With improved living standards, people are less likely to be content with items of mass production; they are more likely to seek a personalised experience, customised services, and diverse choices of consumption goods. Therefore, some scholars have pointed out that rural creative products can offer alternatives (Collins and Cunningham 2017). In addition, rural creative industries can be a catalyst for generating more financial returns in the sectors of services, manufacturing, technology and tourism, encouraging social interaction and cultivating community spirit. Improved infrastructure and physical environment can be driven by the creative sector and consequently transform public perceptions of the countryside. The creative sector has links with both the supply-chain and consumer sectors (White 2010). Its impacts on other sectors' innovation and creativity may exceed the creative sector's own direct contribution. For instance, visitors attending a music event in the countryside may purchase goods and services from the retail and hospitality sectors (WDC 2009; White 2010). In a nutshell, remote locations and physical distances, conventionally considered barriers for developing the creative sector in the countryside, could be desirable features favoured by some types of creative production.

\section{Classifications of Creative Industries: What Suit- able for Rural Areas?}

An overview of the spectrum of creative activities is conducive towards identifying the types of creative industries that may be more suitable or thrive better in rural areas. Classifications of creative industries differ from country to country. Many countries have defined their creative industry categories by adapting the classification proposed in Creative Industries Mapping Document 1998 published by Britain's Department of Culture Media and Sport (DCMS) (Collins and Cunningham 2017). As the first and the most popular classification, the document defines 13 categories of creative industry: advertising; architecture; art and antiques market; crafts; design; designer fashion; film and video; interactive leisure software; music; performing arts; publishing; software and computer services; television and radio. Inevitably, this most widely cited classification has been criticised (fairly or unfairly) by some scholars for the various reasons, such as: its limited number of categories to define and divide various creative sectors; its omission of some obvious cultural production (e.g. heritage, museums, and recreation); the difficulty it presents in separating creative from noncreative work (e.g. designers in the car industry); and its incapability to factor in some sectors' economic output (e.g. crafts) (Collins and Cunningham 2017).

Admittedly, there are some limitations in the DCMS classification, but it has proven useful in practice and helped creative industries gain a foothold in government legislation and policy support. Unsurprisingly, many scholars and organisations have attempted to adapt and improve this classification, seeking to add more precision to the classification to reflect the multifaceted dimensions of creative industries. In and by itself, classification is a simplified version of complex reality; naturally, it is impossible (if not pointless) to state that one classification is 
Figure 2 Rural creative industries by sectors and broad categories (Source: WDC 2009).

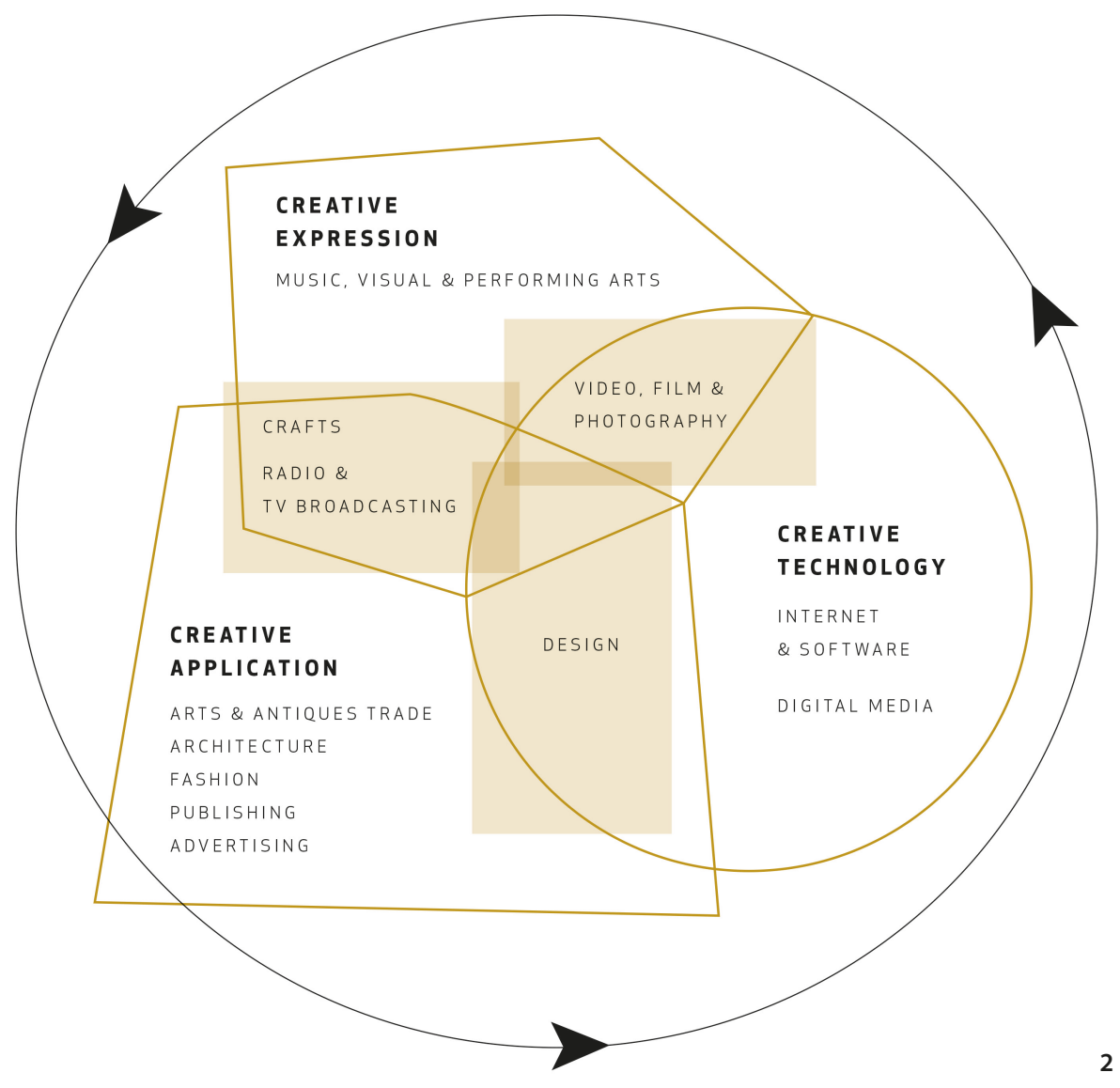

better than another or which is 'right' or 'wrong' (Throsby 2008). The point with a classification is having an adaptable, workable framework to better understand the intrinsic nature (though often dynamic and sometimes transitory) of creative industries.

Among numerous amended versions of classification, one proposed by Ireland's Western Development Commission (WDC) has received recognition from many researchers. Arguably, it is the most influential work for the study of rural creative industries in the British Isles and beyond (WDC 2009; White 2010). First published in the WDC's report Creative West: The Creative Sector in the Western Region (2009), this classification of creative enterprises in rural areas was advanced based on baseline research. The research aimed to stimulate interest in developing creative sectors among stakeholders both within and outside the Western Region, where $67.8 \%$ of the population live in the countryside (WDC 2009; Central Statistics Office 2007).

Adapted from the DCMS classification, the WDC classification categorises 12 individual creative sectors into three broad creative categories-creative application, creative expression, and creative technology (Figure 2). 'Creative application' is defined as 'industries that develop products or services primarily based on meeting a market demand'; 'creative expression' involves 'industries where products or services are developed for audiences with an expressive story in mind'; and 'creative technology' refers to 'industries which rely most on technology and digital media, particularly for their core functions' (WDC 2009, 28-29). Inevitably, some creative sectors fall into more than one of the three categories. For instance, the sectors of crafts, radio, and TV broadcasting overlap the categories of 'application' and 'expression'. Indeed, the crafts industry delivers products not just for practical needs but also with artistic expression; the radio and TV broadcasting sectors provide services to entertain audiences and fulfil their needs. Similar problems in classification occur when measuring the creative economy. The exclusion of the economic output of creative workers who work outside the creative sector (e.g. designers in the car industry) and the inclusion of noncreative workers who work in the creative sector have been an ongoing debate and unresolved issue (Higgs and Cunningham 2008). Following this line of reasoning, it is clear that creative industries cannot be strictly defined, as different creative categories and industries invariably interact with one another. 


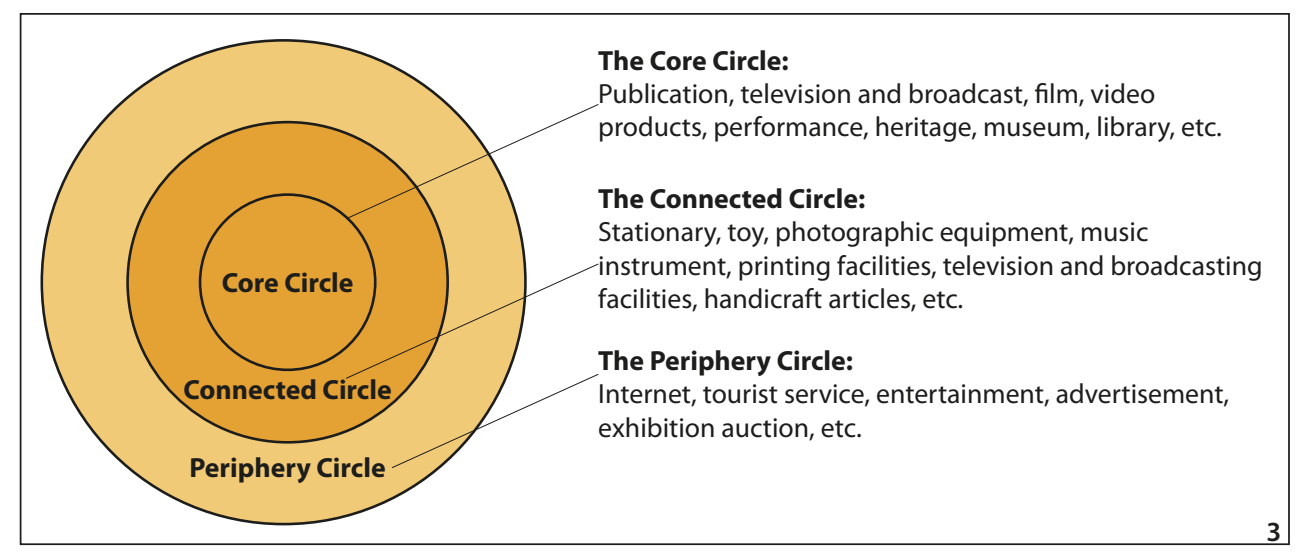

Figure 3 The Chinese classification of cultural industries published in 2004 (Source: adopted from National Statistics Bureau 3 2004)

Outside the British Isles, particularly in the nonEnglish-speaking world, different countries and regions appear to have different views on the definition of 'creative industries' and how to term such activities. For instance, Japan and South Korea use the term 'content industries' in lieu of 'creative industries'; China, however, employs the term 'cultural industries' in all national-level documents (e.g. those published by the Communist Party of China, the Central Committee, and the State Council) ${ }^{1}$. At city and regional levels, variations in terminology also occur. Beijing, Hong Kong, and Taiwan use the expression 'cultural and creative industries', with the emphasis on the cultural connotations of creative productions; by contrast, Shanghai and China's coastal regions tend to adopt the British term 'creative industries'. Xiang and Walker (2013) argue that these terms have subtle differences in meaning, but essentially they all express a single entity: it is based on individual creativity in the creative sphere; it incorporates modern technology and new media; it is oriented towards international markets; it combines product management and business operation; and it integrates industrial management and capital management. This paper employs the term 'creative industries' for alignment with the wording used in local government policies and regulation; however, the term 'cultural industries' occasionally appears when national policies and government reports are cited.

Classification of creative industries has also reflected the characteristics of local economies and the cultural peculiarities of a country or region. Focusing on China, the state government published its first classification in the National Statistics Bureau's report, titled Classification of Cultural and Related Industries 2004 ( 文化及相关产业分类 2004). Defining cultural industries as activities providing culture, entertainment products and services to the public, and the assemblage of activities related to these cultural activities', the report divides cultural industries into three levels of relevance: core, peripheral, and connected activities (Figure 3) (National Statistics Bureau 2004, 11). This first classification, however, failed to encompass some existing or emerging industries that rely heavily on knowledge innovation and intellectual creativity, such as design, creative services, and new media. To rectify this omission and capture growing diversity in creative industries, an amendment to that classification was released in 2018, which includes nine major categories, being further divided into 43 categories, and 146 sub-categories. This three-level categories in the 2018 classification denote an increasing level of specificity, which is different from that specified in the 2004 classification, underlining the degree of relevance (National Statistics Bureau 2018). The nine major categories are as follows:

1. News and information services,

2. Content creation and production,

3. Creative design services,

4. Cultural transmission channels,

5. Investments and operations for cultural industries,

6. Cultural and recreational services,

7. Subsidiary production and intermediary services for cultural industries,

8. Equipment production for cultural industries, and

9. Terminal production for cultural consumption.

Roughly speaking, the first six categories fall in the area of 'core' creative sectors defined in the 2004 classification; the last three are more related to the 'connected' sectors. With its 146 sub-categories, this amended classification became very complex and somewhat cumbersome; yet it failed to include some related industries (Xiong and Fu 2012).

If comparing with the WDC's classification that distinguishes different types of creative industries according to their nature (application, expression, and technology), the Chinese classification adds specification by considering the 
different phases of the process of creativity-related production (Table 1). For instance, the WDC classifies 'crafts' as a single category, but the Chinese classification further divides 'crafts' into two phases: 'content creation and production' and 'sales' of arts and crafts, which fall, respectively, into the major categories of '2. Content creation and production' and '4. Cultural transmission channels'.

Owing to the different rationales behind the classifications, it is not intuitively obvious which of the nine major categories in the Chinese classification match the WDC's categories for rural areas. However, after carefully examining the 43 categories, it is evident that those in the major categories of '2. Content creation and production' and ' 3. Creative design services' are thematically related to those specified in the WDC's classification and are suitable for the rural context. In addition to these two major categories, which are highly relevant to the WDC's rural categories, another two major categories ('1. News and information services' and '4. Cultural transmission channels') are also relevant to the rural context, though with a relatively moderate degree. This means that all the categories and sub-categories within the two high-relevance major categories $(2,3)$ and most of those in the two mid-relevance categories $(1,4)$ are suitable for the rural context.

It should be noted that China has regarded tourism as a key driver for spurring the economic growth of creative industries-in both legislation and practice. Some rural areas, especially in coastal regions and Sichuan (landlocked province), have long relied on tourism for economic growth and a source of livelihood (Wang 2016). While the WDC does not include rural tourism in its classification, the major category ' 6 . Cultural and recreational services' has developed rapidly in China over the past two decades and significantly improved the quality of life of some rural communities.

Apart from the different natures of creative industries that may affect their suitability for relocation to a rural setting, the different sizes of creative enterprises and ventures should also be strategically encouraged and supported by local governments in the process of developing the rural creative sector. At the initial stage, it is more feasible and viable for home-based enterprises, small-scale business, freelancers, and self-employed workers to sustain themselves and thrive (White 2010). Accordingly, it is easier to develop industries that rely on individual creativity and skills; examples include music and visual and performing arts in Ireland's category of 'creative expression' and arts and crafts manufacturing in '2. Content creation and production' in the Chinese classification (e.g. female handicraft workers; Figure 4). By contrast, industries that usually depend on large companies and industrial clusters are expected to encounter some difficulties if trying to establish themselves in rural regions; examples are those in the sector of Internet technology and software development in the WDC's category of 'creative technology'. Relocating large corporates to rural areas would require more infrastructural investment and preferential policy support from the government; on this account, such costly undertaking would only be considered at a later stage of development when an agglomeration of creative industries has appeared.

\section{Issues of Developing Creative Industries in Rural Regions}

Before analysing the problems of China's creative sector in rural areas, it would be beneficial to identify the issues and challenges that such areas have commonly faced in developing those sectors. In the study by Burns and Kirkpatrick (2008) on rural East Midlands in England and research by the WDC (2009) on Western Ireland, a threepillar framework-creative people, creative place, and creative support-was used to categorise issues related to rural creative industries. This framework was formulated by identifying key issues for the rural creative sector after conducting a series of interviews with business investors, service providers, government agencies, and other relevant stakeholders (WDC 2009).

The issues of creative people are 'related to the level of skills and creativity within the region's population, provision of local training courses and the activities of educational institutions, as well as the level of diversity' (WDC $2009,53)$. In the survey of Western Ireland, companies in creative industries found it difficult to recruit employees to work in rural areas; industries categorised as 'creative technology' experienced the greatest difficulty. This reflects the fact the sector related to information and communications technology tends to prefer urban locations. Some studies have found that the creative workforce is highly mobile, and this raises the challenge of retaining creative workers in the countryside (WDC 2009; White 2010; Young 2013). Low inward migration has posed a threat to diversity in the social composition and economic activities of rural regions. Retaining skilled workers currently resident in the countryside is as important as attracting new ones. Ireland's current policy, for example, has been criticised for its sole focus on attracting new skilled workers to move to rural districts with no considerations for sustaining and encouraging established skills (WDC 2009). 
Table 1 The revised Chinese classifications of cultural industries published in 2018, and the degree of relevance to the WDC's classification of creative industries (Source: the authors).

\begin{tabular}{|c|c|c|c|}
\hline \multicolumn{3}{|c|}{ Classification of Cultural Related Industries 2018, China (National Statistics Bureau, 2018) } & \multirow{2}{*}{$\begin{array}{l}\text { Degree of Relevance to } \\
\text { WDC's Creative Industries' } \\
\text { Classification }\end{array}$} \\
\hline & $\begin{array}{l}\text { Nine Major } \\
\text { Categories }\end{array}$ & 43 Categories & \\
\hline \multirow{6}{*}{$\begin{array}{l}\text { Cultural } \\
\text { Core Areas }\end{array}$} & $\begin{array}{l}\text { 1. News and Information } \\
\text { Services } \\
\text { 新闻信息务 }\end{array}$ & $\begin{array}{l}\text { - News Services 新闻服务 } \\
\text { - Newspaper and Information Services 报纸信息服务 } \\
\text { - Radio and TV information Services 广播电视信息服务 } \\
\text { - Internet Information Services 互联网信息服务 }\end{array}$ & Middle \\
\hline & $\begin{array}{l}\text { 2. Content Creation and } \\
\text { Production } \\
\text { 内容创作生产 }\end{array}$ & $\begin{array}{l}\text { - Publishing Services 出版服务 } \\
\text { - Radio, Film and TV Programs Production 广播影视节目制作 } \\
\text { - Creative Performance Services 创作表演服务 } \\
\text { - Digital Content Services 数字内容服务 } \\
\text { - Content Preservation Serivces 内容保存服务 } \\
\text { - Arts and Crafts 工艺美术品制造 } \\
\text { - Art Ceramics 艺术陶瓷制造 }\end{array}$ & High \\
\hline & $\begin{array}{l}\text { 3. Creative Design Service } \\
\text { 创意设计服务 }\end{array}$ & $\begin{array}{l}\text { - Advertising Service 广告服务 } \\
\text { - Design Services 设计服务 }\end{array}$ & High \\
\hline & $\begin{array}{l}\text { 4. Culture Transmission } \\
\text { Channels 文化传播渠道 }\end{array}$ & $\begin{array}{l}\text { - Publication Distribution 出版物发行 } \\
\text { - TV, Broadcast/Cable Network Providers 广播电视节目传输 } \\
\text { - Distribution and Screening of Broadcast, Film and TV Programs } \\
\text { 广播影视发行放映 } \\
\text { - Artistic Performance 艺术表演 } \\
\text { - Internet Platform for Cultural Entertainment 互联网文化娱乐平台 } \\
\text { - Art Auction and Agency 艺术品拍卖及代理 } \\
\text { - Arts and Crafts Sales 工艺美术品销售 }\end{array}$ & Middle \\
\hline & $\begin{array}{l}\text { 5. Investments and Opera- } \\
\text { tions for Cultural Indus- } \\
\text { tries 文化投资运营 }\end{array}$ & $\begin{array}{l}\text { - Investment and Asset Management 投资与资产管理 } \\
\text { - Operations Management 运营管理 }\end{array}$ & $\mathrm{N} / \mathrm{A}$ \\
\hline & $\begin{array}{l}\text { 6. Cultural and Recreational } \\
\text { Services } \\
\text { 文化娱乐休闲服务 }\end{array}$ & $\begin{array}{l}\text { - Entertainment Services 娱乐服务 } \\
\text { - Tourist Sites Services 景区游览服务 } \\
\text { - Leisure Tourism Services 休闲观光游览服务 }\end{array}$ & N/A \\
\hline \multirow{3}{*}{$\begin{array}{l}\text { Cultural } \\
\text { Connected } \\
\text { Areas }\end{array}$} & $\begin{array}{l}\text { 7. Subsidiary Production } \\
\text { and Intermediary Services } \\
\text { for Cultural Industries } \\
\text { 文化辅助生产和中介服务 }\end{array}$ & $\begin{array}{l}\text { - Traditional and Painting Stationery Supplies for Cultural Industries } \\
\text { 文化辅助用品制造 } \\
\text { - Printing Reproduction Services 印刷复制服务 } \\
\text { - Copyright Services 版权服务 } \\
\text { - Conference and Exhibition Services 会议展览服务 } \\
\text { - Agency Services for Cultural Industries 文化经纪代理服务 } \\
\text { - Rental Services of Equipment (Supplies) for Cultural Industries } \\
\text { 文化设备（用品）出租服务 } \\
\text { - Research and Training Services for Cultural Industries } \\
\text { 文化科研培训服务 }\end{array}$ & N/A \\
\hline & $\begin{array}{l}\text { 8. Equipment Production } \\
\text { for Cultural Industries } \\
\text { 文化装备生产 }\end{array}$ & $\begin{array}{l}\text { - Printing Equipment Manufacturing 印刷设备制造 } \\
\text { - Radio, TV and Film Equipment Manufacturing and Sales } \\
\text { 广播电视电影设备制造及销售 } \\
\text { - Video Recording Equipment Manufacturing and Sales } \\
\text { 摄录设备制造及销售 } \\
\text { - Performing Equipment Manufacturing and Sales } \\
\text { 演艺设备设备制造及销售 } \\
\text { - Amusement Equipment Manufacturing 游乐游艺设备制造 } \\
\text { - Music Instrument Manufacturing and Sales 乐器制造及销售 }\end{array}$ & Low \\
\hline & $\begin{array}{l}\text { 9. Terminal Production for } \\
\text { Cultural Consumption } \\
\text { 文化消费终端生产 }\end{array}$ & $\begin{array}{l}\text { - Stationery Manufacturing and Sales 文具制造及销售 } \\
\text { - Pen and Ink Manufacturing 笔墨制造 } \\
\text { - Toy Manufacturing 玩具制造 } \\
\text { - Festival Supplies Manufacturing 节庆用品制造 } \\
\text { - Manufacturing and Sales of Information Services Terminal } \\
\text { 信息服务终端制造及销售 }\end{array}$ & Low \\
\hline
\end{tabular}


Figure $4 \mathrm{~A}$ female handicraft worker making embroidery in rural Anshun, Guizhou Province (Source: MOMA Design Company)

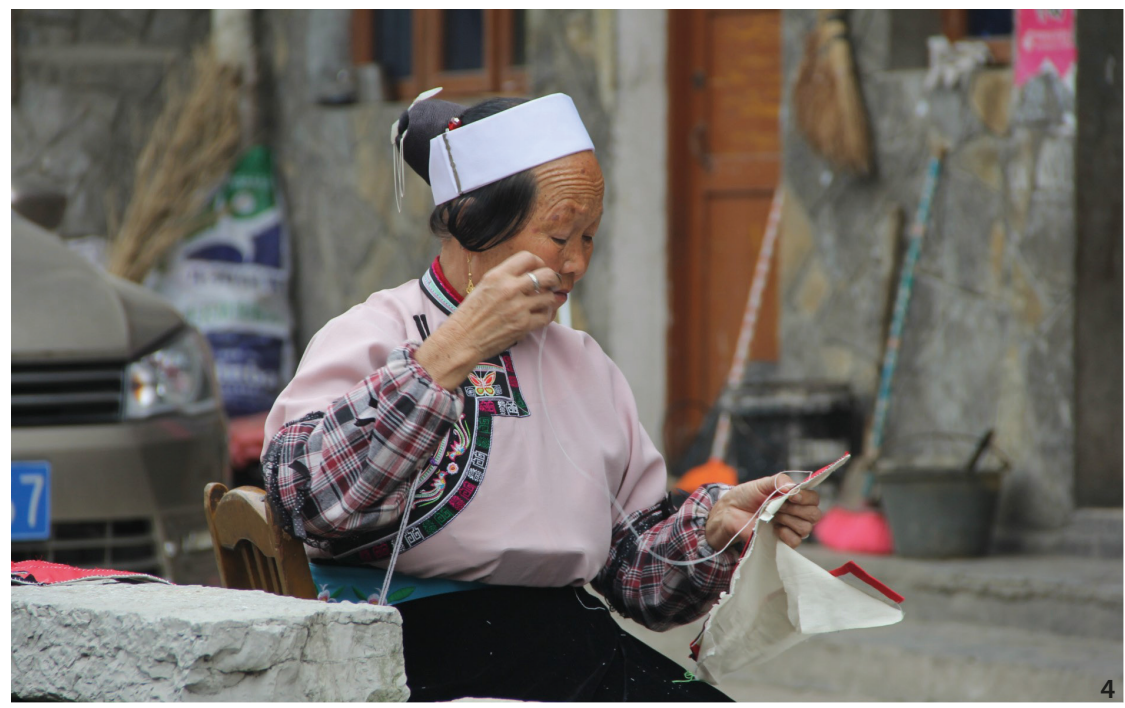

The creative place is 'related to the attractiveness of the region including its landscape, heritage, built environment, infrastructure, social network and quality of life' (WDC 2009, 53). In the Creative West report, issues related to the creative place are mainly concentrated on the following five aspects: quality of life; natural environment and creative inspiration; connectivity; workspace and infrastructure provision; and planning and development. The quality of life and natural landscape are factors that highly influence location choice among creative workers. Especially for creative workers in the categories of creative expression and application, such factors as remoteness, landscape, natural surroundings, space and heritage, waterways, and lighting are significant for their creativity to thrive. One study in the United States determined that the amenities of rural areas attract self-employed, mobile creative workers, such as younger working artists and those involved in the performing arts (Markusen and Schrock 2006). In rural Ireland, problems such as a lack of suitable low-cost workspaces, incomplete road networks, and insufficient broadband capacity and connectivity are generally deemed as the physical barriers to attract creative enterprises and workers (WDC 2009). However, some scholars consider that improvements in connectivity may lead to a loss of isolation or remoteness and a risk of spoiling the rural character through overly urban-centred development plans (Gibson 2014b; White 2010; WDC 2009). Other challenges include a lack of appropriate creative infrastructure and amenities (e.g. studios, theatres) as well as insufficient job opportunities for current and new creative workers (WDC 2009).

Creative support refers to 'the facilitating policies and programmes available to the creative sector, such as funding, networking opportunities and marketing capabilities' (WDC 2009, 53). The inadequacy of creative support in Western Ireland include: poor networking among creative companies located in different counties; a low level of joint projects; lack of information about funding opportunities; lack of showcasing of local talent in tourism; lack of awareness of the role of creative industries in innovation within non-creative sectors, such as manufacturing, financial services, and tourism; and the distance from urban-based trade associations (WDC 2009). The main problems for this region are a lack of financial support and appropriately tailored funding opportunities for creative companies. Its development mode has mainly been county-based; collaborative regional approaches are rarely adopted (WDC 2009).

Most of the issues in the Western Region of Ireland are consistent with findings in other rural regions, such as the East Midlands in England and Montana and Arkansas in the United States (Burns and Kirkpatrick 2008; Stolarick et al. 2011; McGranahan and Wojan 2007; Regional Technology Strategies Inc. 2003, 2007). Whereas the factors of quality of life and physical environment have had the strongest effect on attracting creative workers to the countryside, infrastructure, accessibility, and networking are the key constraints in operating creative businesses in rural locations. Accordingly, the above findings can be considered an important reference for China's situation.

\section{Pathways to a Creative Chinese Countryside}

With reference to the three-pillar framework of creative people, creative place, and creative support, this section 
examines issues in China related to promoting creative sectors in rural areas. Comparing the situation in China with that in other rural regions reveals common issues and challenges in fostering the development of creative sectors, yet there are also some issues unique to China.

\section{Creative People: Training Rural Creative Workers}

Currently, the lack of creative people has been a key issue for China in developing creative industries in urban areas; that clearly also applies to the countryside. Corporates in creative sectors have reported that university graduates are not equipped with a set of essential skills that are required in practice. This situation may have partly resulted from low employment rates among graduates from educational disciplines related to creative industries (CCIA 2018). The Chinese government and related organisations have recognised this issue and made proposals for developing creative talent. In 2014, the State Council issued Several Opinions on Promoting the Development of Cultural Creativity and Design Services and Related Industries (关于推进 文化创意和设计服务与相关产业融合发展的若干意见). A series of programmes for supporting creative talent were then launched to remove the stigma from 'Made in China' (中国制造) and promote instead the brand 'Created in China' (中国创造) (State Council of China 2014). In the same year, the China Creative Industry Alliance (CCIA, 中 国创意产业联盟 ) launched the China Creative Entrepreneur Talent Cultivation Project (CCIA 2018), which aims to solve the current problem of a lack of creative individuals by cultivating creative talent for practical application. However, there is at present no programme for developing creative talent to support rural regions in China. It is conceivable that the lack of creative talent in the countryside is more serious than big cities.

In contrast to the focus of the Irish policy in attracting creative workers from urban areas (including travelling artists) to the countryside, China has appeared to place the emphasis on harnessing traditional skills and transforming local artisans into designers. Although currently no rural-centric national policies have been enacted for revitalising or refashioning traditional crafts and incorporating them into design industries, some initiatives have been launched by local governments and conducted in collaboration with the private sector. For instance, Shanghai Municipal Government and MOMA Design Company collaborated in launching the Design for County project in 2011. The project aims to utilise design approaches towards reviving traditional industries in abandoned industrial sites in rural areas, by converging government support, practitioner know-how, and local craft skills to achieve cross-sector cooperation. Several projects have been carried out, for example, the training centre in Rizhao (Shandong), Ma'anshan (Anhui), and Baoying (Jiangsu) (MOMA 2019). At Baoying Training Centre, for example, rural residents who wish to become creative industry practitioners can enrol on training courses to learn how to make crystal glass products or master needle stitching (Figure 5). Although this cross-sector collaborative endeavour has not yet produced significant returns in economic revenue owing to various factors, access to and experience in receiving training for craft skills and design professionals have been appreciated by local skilled workers. This project has shown that with or without a national policy in place, local governments are often key actors in initiating and implementing projects towards developing and making China's rural creative sector prosper. It should be noted that several MOMA Design Company projects have been set up in former industrial complexes previously established as a result of the 1980s TVE policy, which will be elaborated in the following section.

\section{Creative Place: Valuing Rurality}

China covers a vast area, and so issues related to creative place in different rural regions vary geographically. Generally speaking, three rural issues (rural areas, agriculture, and farmers) have always been the primary focus for national policies on rural development (Lin 2003). Since economic reform in 1978, China's rapid urbanisation has attracted the migration of rural populations to the cities, leading to increasingly severe rural hollowing (Liu and Liu 2010). Out-migration has resulted in damage to rural economies and social stability. In addition, the lack of community and transport facilities and environmental issues caused by modern farming and manufacturing activities as well as rural households are the thorny problems that need to be addressed, before we envisage the countryside as milieus of creativity (Liu and Liu 2010).

As with Britain and Ireland, China needs to prioritise improvement of its infrastructure, environment, and quality of life to enhance the attractiveness and liveability of its rural areas. Such improvement can appeal to creative workers to relocate and also induce urban migrant workers to return to the countryside. Arguably, the environment and quality of life are the most important elements in inducing creative workers and companies to relocate. In addition to basic facilities (such as schools and hospitals), broadband connectivity and road networks are equally important for developing creative industries in rural areas. 
Figure 5 Rural skilled workers have been trained to make handmade products at MOMA's Baoying Training Centre (Source: MOMA Design Company)

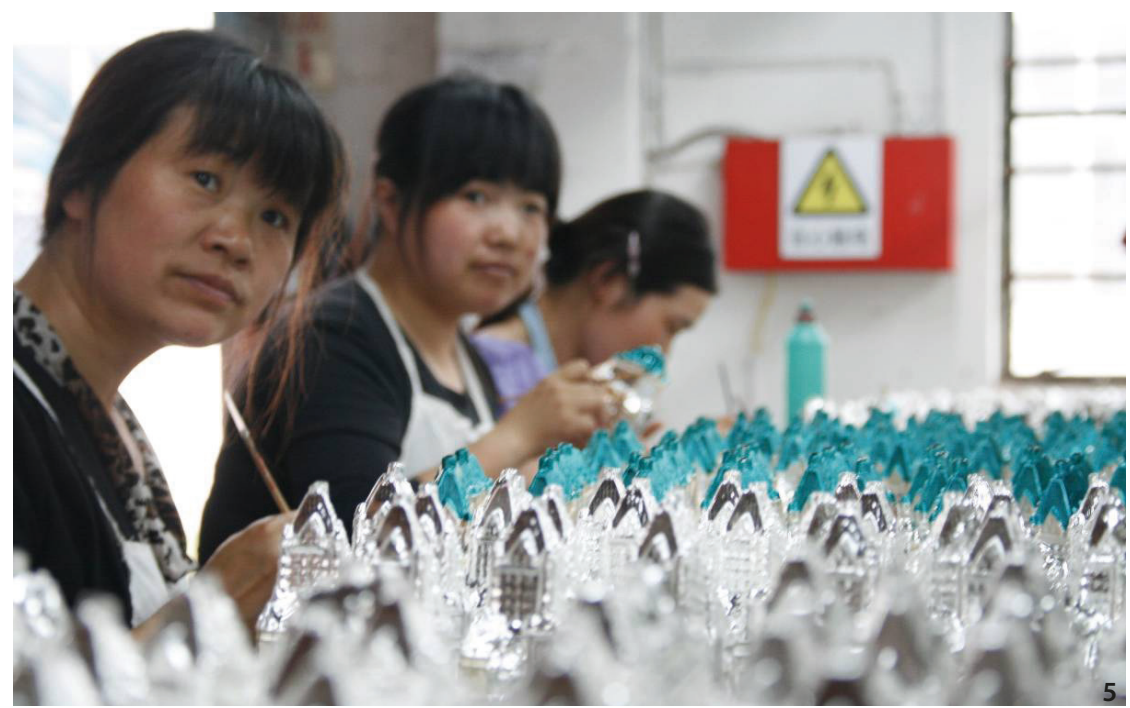

Some empirical studies have shown that using broadband productively and intensively can promote labour demand and innovative behaviour in firms (Vergara and Feldman 2018). In many cases, the lack of connectivity has a negative impact on rural creative industries; however, for some types of creative companies and workers, high-speed broadband connectivity can easily outweigh the drawbacks of remote locations and physical distance (Townsend et al. 2016). In a study of creative industries in rural Scotland, Leanne Townsend et al. (2016) conclude that download speed is crucial for workers in the creative sector and 2 megabits per second of broadband access is regarded as the minimum necessary to achieve the productivity of workers equivalent to those working in cities.

The natural and agricultural landscape, the built environment, cultural heritage, and social networks that constitute the rurality of a place should be carefully preserved. Local culture, folks, and crafts help foster creativity. Fairs, festivals, and events promoting creative industries should be encouraged, for they have social and situational values and can also showcase and capitalise on local creative talent and skills. For instance, Latitude Festival in Britain features performance and live music, which attracts thousands of people every year to the Suffolk countryside (Figure 6).

\section{Creative Support: Establishing Policies and Fund- ing Programmes}

The creative support issue in China is highly related to national policy. At the national level, the Guideline on Emerging Sectors of Strategic Importance during the $13^{\text {th }}$ Five-Year Plan Period (2016-20) highlights the importance of digital and creative industries (State Council of China
2016). Additionally, some metropolitan cities, such as Beijing, Shanghai, and Shenzhen, have also given high priority to creative industries in their economic development plans. However, policies and supporting programmes for the rural creative sector are still deficient. Lack of funding, networking opportunities, and marketing capabilities are common problems for creative companies in rural China. Before supporting policies are formulated, research needs to be undertaken on the actual situations and issues of rural China and effective measures for developing the creative sector.

In many countries, developing rural creative industries has been enshrined in national policy. Some specific departments and organisations have been established to promote, manage, and study rural creative industries. Thus, framing a national policy for the rural creative sector as a whole is imperative in China. Currently, there are many funding opportunities for creative companies in cities, but rural regions remain underrepresented. Governments at different levels should establish funding programmes for the rural creative sector and ensure that funding schemes are available for rural creative businesses. A good example of funding support for rural creative enterprises is Northern Ireland's Creative Industries Innovation Fund in 2008 (WDC 2009). In addition to policy aspects, enhancing the partnership between private and public sectors as well as increasing interactions between creative and other sectors will contribute to a vibrant creative sector. At present, small-scale businesses constitute the majority in rural China, yet few collaborations take place among different enterprises. Therefore, local governments and non-government organisations should be encouraged to deliver regular meetings and workshops to provide information 


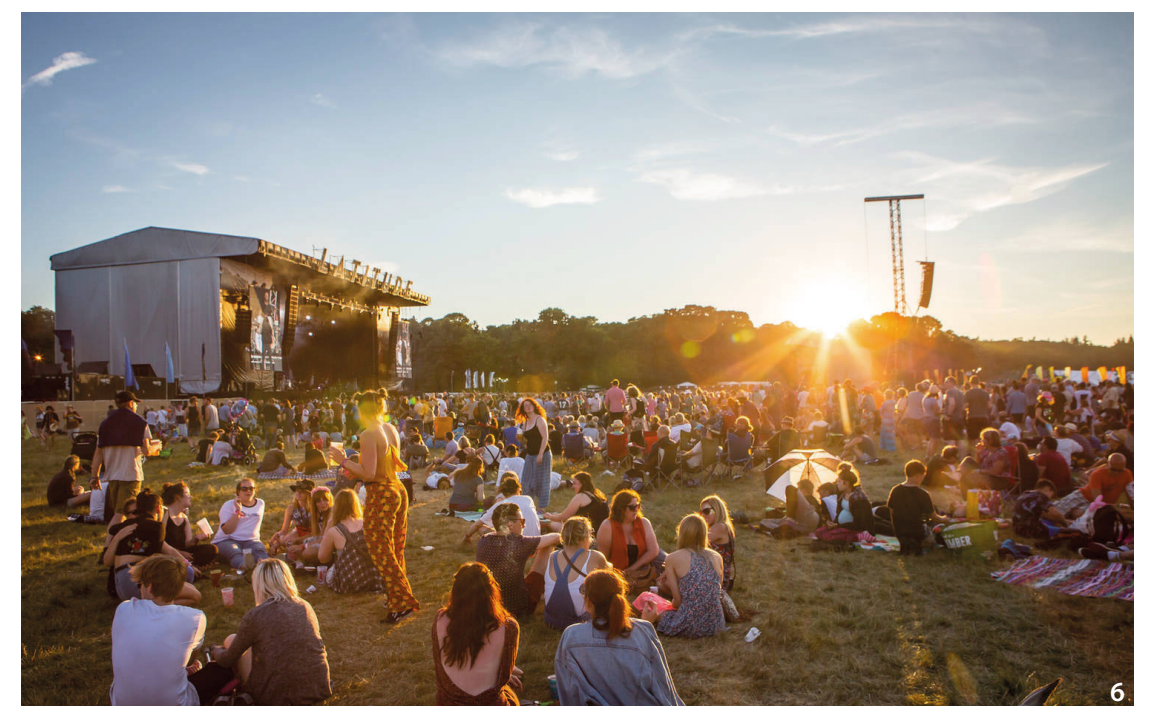

Figure 6 Latitude Festival in Henham Park, Suffolk, UK (Source: Latitude Festival official).

and opportunities for people working in creative sectors to interact and establish informal networks. In so doing, it will enhance networking, generate more joint projects, and increase opportunities for social and cultural interactions among creative companies and workers.

\section{TVEs as Incubators for the Creative Sector in Rural China}

As noted above, several projects in Jiangsu Province have attracted creative sectors to rural areas by using former industries sites. Most of these industrial complexes were established in the 1980s through the TVE policy, which aimed to boost China's rural economy by introducing manufacturing industries to diversify the income sources of rural communities (Jiang 2002; Wu 2007). Three main features characterised the industrial establishments of TVEs:

1. Investors, operators, and employees of TVE factories are mainly farmers;

2. They are located in the countryside;

3. They have been producing non-agricultural products (Jiang 2002).

The TVE policy encouraged rural communities to set up factories close to their villages. It capitalised on their shareholding of land ownerships and collectivism inherited from the people's commune (an administrative unit for production in rural China from 1958 to 1983). In particular, southern Jiangsu Province achieved remarkable economic success, and it became known for its 'Sunan model' for TVE development (Chen and Zhang 2008). However, over the past two decades or so, more and more industrial establishments of TVEs in the region have become obsolete. Regrettably, after ceasing production, the physical structures of TVEs have either been abandoned or demolished to make way for new development or land consolidation (Wu 2007).

\section{TVEs as Heritage of Rural China}

China began protecting and conserving historic buildings and sites relatively late and formulated its heritage legislation several decades after Western countries did so. The release of the Notice on Strengthening Industrial Heritage Protection in 2006 marks the beginning of industrial heritage protection in China (State Administration of Cultural Heritage 2006). A decade later, the first and second batches of the China Industrial Heritage Protection List were released in 2018 and 2019, which recognise 200 industrial properties built between the 1840s and 1940s as being of national importance (China Association for Science and Technology 2018, 2019). It cannot be plausibly argued that the former industrial complexes of TVEs are comparable to those nominated on the China Industrial Heritage Protection List. Built in the 1980s and 1990s, the factory buildings of TVEs are unremarkable in terms of architecture value. However, as ordinary and unassuming as they appear, these buildings have withstood the radical socio-economic transformation of rural China following economic reform in 1978, thereby representing a common heritage of rural societies.

TVE industrial establishments represent 'the industrial heritage [that] is of social value as part of the record of the lives of ordinary men and women, and as such it provides an important sense of identity', as stated in the Nizhny Tagil Charter for the Industrial Heritage (TICCIH 2003). TVEs are carriers of local memory-of at least 
one generation of workers and families - and record the everyday life of rural communities at that time. Chinese scholars have observed that the industrial buildings and sites of state-owned enterprise established in the $20^{\text {th }}$ century constitute an under-represented category in China's current heritage protection scheme (Que 2007; Wang and Wang 2018). Though established and developed locally by rural enterprises (rather than by state-own companies), TVE industrial complexes represent an episode of China's industrialisation history and, arguably, are one of the most eminent embodiments of China's economic reformsymbolically comparable to the massive socio-economic transformation of Shenzhen.

On this account, the physical relics of TVEs should be regarded as the industrial heritage of rural China's recent past. Certainly, the buildings in these industrial establishments are certainly not high-quality architectural structures with exquisitely designed details and, thus, do not warrant heritage status and statutory protection. However, they are undoubtedly of communal value and socio-economic importance for local communities and should be retained. Reusing former TVE factories for creative industries, therefore, is not just a practical solution for recycling and repurposing existing buildings; it is also a strategic manoeuvre to conserve the residual industrial landscape of post-reform rural China and sustain existing social networks as well as collective memoires of rural communities.

\section{Precedent Studies: Sanniaocang Art Space (Nan- jing) and Zhujiadian Brick Kiln Museum (Kun- shan)}

The adaptive reuse of abandoned TVE sites for creative industry appears to be a plausible scenario for rural China. In particular, the large number of TVEs in Jiangsu Province offers considerable potential for creative industries to develop in the countryside. The industrial relics of TVEs have architectural attributes that are conducive to creative production-comparable to those in urban areas. This coincides with our observation that some derelict TVE industrial precincts have caught the attention of creative enterprises and been transformed into spaces for creative production: Sanniaocang Art Space in Nanjing (converted from a derelict gypsum factory) and Zhujiadian Brick Kiln Museum in Kunshan (repurposed from an old brick kiln).

Sanniaocang Art Space is an example of individual initiative in repurposing an abandoned rural industrial site for creative activities. It is located in Huashu village, Qixia district, Nanjing city, Jiangsu Province. In 2014, a group of young art students started working on the abandoned gypsum factory over a period of several years. They transformed it into a multi-functional art space for painting, design, sculpture, photography, animation, and a virtual reality experience. Local inhabitants admire Sanniaocang Art Space and consider it an 'artist habitat' that has developed from the ruin. Graffiti can be seen everywhere in the area. Most of the installation artworks have been made from waste and recycled materials. Various exhibitions (on folk art, contemporary art, rural photography and handicraft), book fairs and social and charity events have been held in Sanniaocang (Figure 7). A special public lecture series was delivered by artists for prisoners in Nanjing. In addition, in early 2019, five young artists specialising in oil painting, design, and animation took up residence in Sanniaocang Art Space (Figure 8). They were attracted by the unique architectural space and artistic atmosphere of the place. In the first few years of residence, young artists do not have to pay rent, which eases financial pressure for them.

Zhujiadian Brick Kiln Museum is an important project in the regeneration of Zhujiadian village initiated by lower-level government (i.e. village administration). The museum is located in Zhujiadian Village, Jinxi Township, Kunshan county-level city, Suzhou city, Jiangsu Province. Zhujiadian was formerly known for producing 'golden bricks' for the Forbidden City in Beijing (Cui 2018). Before the conversion, some old kilns were still in operation but, due to the migration of younger people, traditional skills could hardly be handed down and the village went into gradual decline.

In 2016, the local government commissioned the design company Land-Based Rationalism D-R-C to redesign the old brick kiln. Architect Kai Cui decided to transform the abandoned factory into a brick kiln museum (Figures 9-11). Converted from a former TVE complex, the museum includes exhibition halls, a brick workshop, multi-purpose halls, and some small classrooms. The original layout, style, and colour of the old factory have been retained. Its original north-south axis and orientation facing the lake have been preserved, and that resonates with the memories of the brickworks among locals (Cui 2018). The conversion project complied with conservation principles by introducing 'micro-intervention' (i.e. minimising changes made to the physical structures) and had an effect in regenerating the whole village. The museum attracted visitors, interested in learning the history of the golden bricks. It gave local inhabitants the opportunity to run businesses near the museum, such as shops, cafés, and guest houses, which helped increase the villagers' income and revitalised the village. 

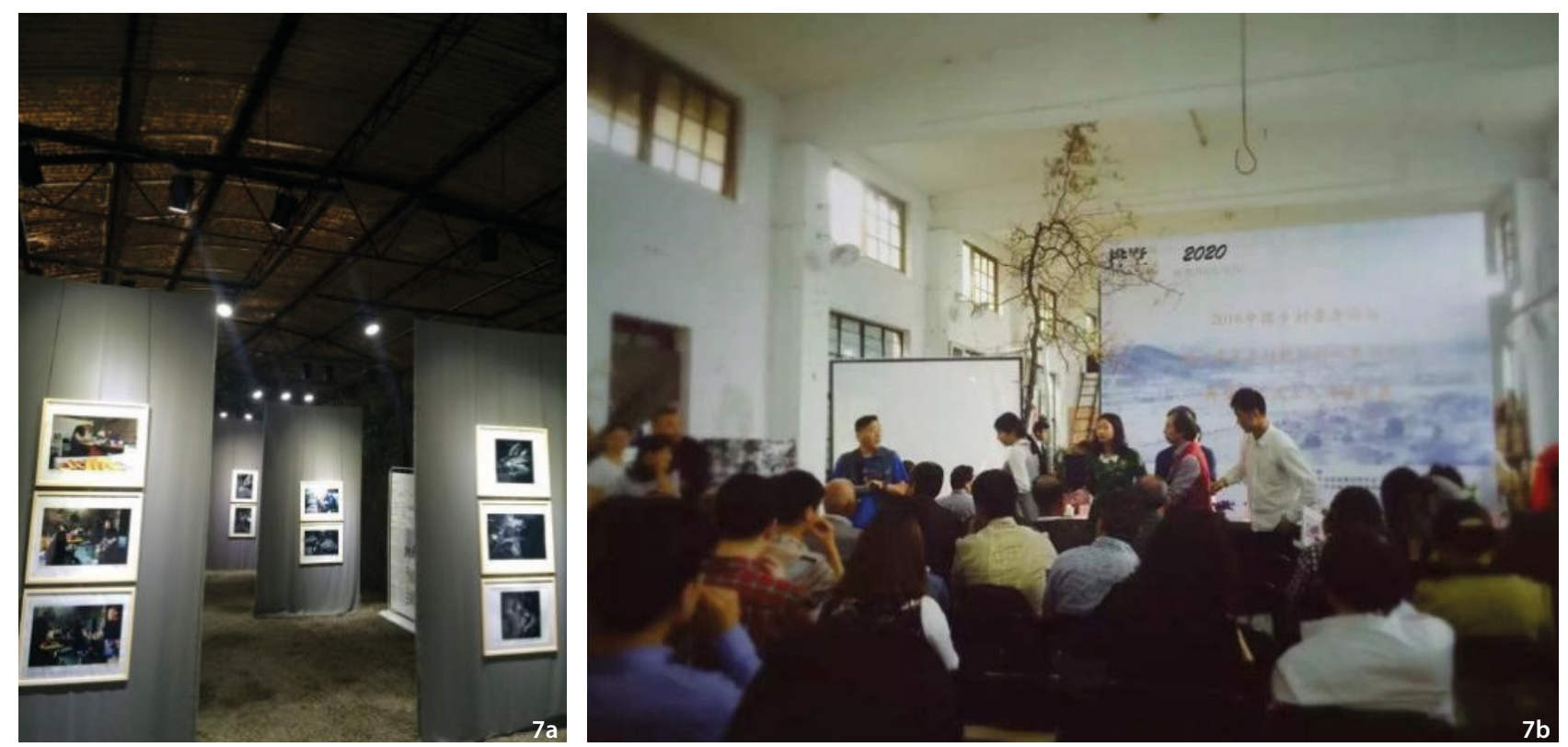

Figure 7a and 7b Various exhibitions and events in Sanniaocang (Source: Jun Guo).

\section{Reflections}

It is clear that projects related to developing creative startups by reusing former TVE industrial sites have grown in recent years. Presumably, this is connected with the Chinese government's concerted efforts and campaigns for rural revitalisation following the introduction of Strategic Plan for Rural Revitalisation (2018-2022) (State Council of China 2018). Local governments have come to realise the potential of developing creative industries to revitalise the countryside and begun promoting such development. Common types of new uses for former industrial sites in China and overseas are museums, public facilities, creative industrial parks, and tourism development (Ye and Li 2007). In terms of investment and development mode, most conversion and regeneration projects for large-scale disused industrial complexes in China have been initiated or operated in public-private partnerships. The government lets out sites and constructs the infrastructure; private developers undertake the construction of the project (Ye and Li 2007; Wang and Wang 2018). In contrast, most former TVE sites are relatively small in scale. To date, most of the conversion projects have resulted in museums and public facilities, and there has been limited integration with tourism and other industries.

Examination of the two cases selected in this study has revealed that the industries developed there fall into the categories of 'content creation and production' and 'creative design services' in the Chinese classification of cultural and creative industries. Sanniaocang Art Space is classified in the sub-category of 'arts and crafts' and 'professional design services', which respectively fit into the two abovementioned categories. In the sub-category of 'museum', Zhujiadian Brick Kiln Museum also comes into the category of 'content creation and production'. These two major categories-'content creation and production' and 'creative design services'-were identified as having a high degree of relevance to rural development, which confirms the findings of studies in the literature review.

Upon an examination of these two cases in terms of the criteria of 'creative people, creative place, and creative support', it is evident that their industrial development is still basic; local villagers' participation in the projects is relatively passive, and they lack government support. With Sanniaocang Art Space, the free art studio attracts some artists, but few local villagers have been involved in developing and operating the project. A key stakeholder in the project is currently negotiating with the Qixia district government for more policy and financial support. However, it remains to be seen whether and when the local government will react to this appeal. Compared with the individual entrepreneur-led initiative of Sanniaocang, Zhujiadian Brick Kiln Museum was a different type of bottom-up initiative, led by village officials. Despite its radical vision for the future and wishful nostalgia for the past, the project has attained limited success. The idea behind this 'micro-intervention' has not been very well received. Public transport to the museum is inconvenient, so visitors usually go there by car. The gift shop in the museum is currently closed because of the small number of tourists, and business has never really blossomed for the nearby guest houses. 

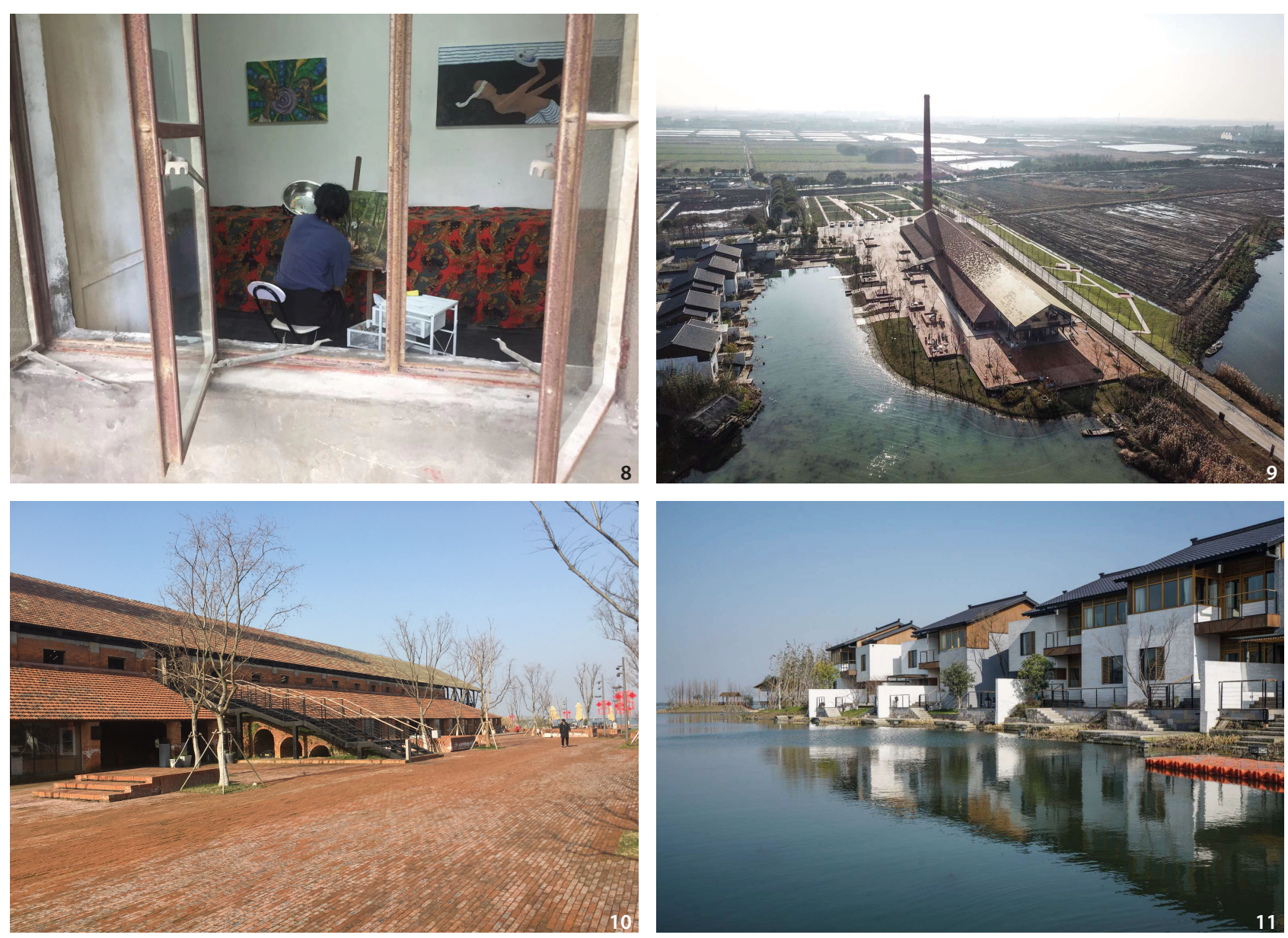

Figure 8 Artists in the art studio in Sanniaocang (Source: Jun Guo).

Figure 9 Bird view of the Zhujiadian Brick Kiln Museum, BNBs and the village (Source: Jiayi Li).

Figure 10 Exterior of the Zhujiadian Brick Kiln Museum (Source: Jiayi Li).

Figure 11 BNBs near the Museum (Source: Jiayi Li).

Regarding how rural cultural industries should be developed, the Guidance on Promoting the Revitalisation of Rural Industries, issued by the State Council in June 2019, indicates some directions. The policy emphasises the significance of using all kinds of intangible cultural heritage resources in rural areas, protecting traditional crafts, and promoting the development of cultural industries with rural characteristics. At the same time, the policy aims to promote the integration of agriculture, culture, tourism, and other sectors, and actively rebrand local produce and agricultural products (State Council of China 2019). Therefore, future studies should examine how to use local rural intangible cultural resources for the development of creative industries; identify ways in which rural creative industries can be integrated with various other industries (such as tourism and industrial design); and determine how to elicit support and attract capital from multiple sectors to contribute to rural revitalisation.

\section{Conclusions}

Despite being currently ignored by policy makers, rural and peripheral regions are not lacking in creativity. The creative sector can offer a place-based approach to excavate the full potential of rural areas-an approach that contributes to economic growth, social well-being, and environmental quality. Promoting creative industries at the regional level can stimulate growth in other sectors, which in turn can reinforce the creative sector. In addition, the potential of creative industries in diversifying local economies and employment opportunities in rural areas cannot be ignored. Amid concerns for rural China, the present research examined issues related to developing creative industries in rural regions with respect to 'creative people, creative place, and creative support'. The issues that China has encountered are very similar to those in other rural regions, such as Western Ireland, Australia, the United Kingdom, and the United States. It is critical to improve the quality of life as well as to safeguard landscapes, 
built environments, and the natural heritage of rural areas, because they hold considerable appeal for creative workers and businesses. The seclusion and remoteness of such areas may be undesirable for some creative workers but attractive to others, allowing them to foster creativity and inspiration. Both physical and virtual connectivity are fundamental to operating a creative business in a rural location; thus, both transport and broadband connections should be improved.

This paper has examined the potential of abandoned industrial sites (TVEs) to act as incubators for rural creative industries in China. As an embodiment of villagebased collective enterprises, the physical remains of TVEs have socio-economic importance and are a repository of collective memories of rural society (Jiang 2002). They should be considered a rural industrial heritage of the recent past, possessing both tangible and intangible value. It is thus critical to reinvent new forms of enterprise for the existing TVE collectives and prevent the deterioration of their disused factories and sites.

The use of former TVE sites is only a small part of rural revitalisation and development efforts for rural creative industries in Jiangsu Province. However, it has the potential to be the most effective of such projects, exerting a multifaceted, positive impact on local communities. In addition to physical transformation (appearance, design) and functional change, issues yet to be explored include: how to guide developers, investors, and individuals so that they can participate in transforming TVE industrial sites; how to make local stakeholders participate more actively in that transformation; and how to connect TVE reuse projects with cultural tourism and rural planning. In June 2019, China's first draft of a law on cultural industry promotion was published with the aim of obtaining public opinion. Support for the development of rural creative industries should be more explicitly stipulated in the law. This would elevate rural regions' preferential policies and financial support to the national level, thereby maximising the great potential of creative industries for future economic growth and cultural prosperity in both urban and rural China.

\section{Note}

1. In China, since introducing the economic reform and open door policy in 1978, the State Council has implemented three key national policies with different focuses: first, on 'economic wealth'; then, 'scientific and technological innovation'; and most recently, 'culture and creativity' (Xiang and Walker 2013). The shift in focus to 'culture and creativity' at the turn of the century corresponds with the fact that the society and economy of urbanised areas of China have become fully developed. The Ministry of Culture in establishing the Cultural Industries Division in 1998 marked the commencement of state government programmes to promote the development of creative and cultural industries. The Cultural Industries Division is responsible for formulating cultural industries policies and guidance. With the publication of Cultural Industry Promotion Plan ( 文 化产业振兴规划 ) by the State Council in 2009, cultural industries have been elevated to the level of national strategy (Xiang and Walker 2013).

\section{Acknowledgements}

This research was supported by the 2019 Suzhou SoftScience Programme (grant no. SR201927) and the Jiangsu Province Program of Science and Technology (grant no. BK20151244). The authors would like to thank Prof. Jiang Feng (South China University of Technology), Prof. Laura Anna Pezzetti (Polytechnic University of Milan) and Mr. Roger Bataille (Mayor of Ervy-le-Châtel, France, and Vicepresident of Association of Characteristic Towns), who gave useful and constructive comments on an earlier version of this paper at the Second International Conference on Built Heritage Studies, organised by Tongji University, 20-21 April 2019. Thanks are also due to Jun Guo and Jiayi Li for providing photos for the cases of Sanniaocang Art Space and Zhujiadian Brick Kiln Museum; and an anonymous reviewer and Dr. Plácido González Martínez, the executive editor of Built Heritage, for their very helpful comments.

\section{Reference}

Balfour, Bruce, Michael WP Fortunato, and Theodore R. Alter. 2018. "The Creative Fire: An Interactional Framework for Rural Arts-based Development." Journal of Rural Studies 63: 229-239.

Battersby, Bryn, and Robert Ewing. 2005. "International Trade Performance: The Gravity of Australia's Remoteness.” Australian Government, The Treasury.

Bell, David, and Mark Jayne. 2010. “The Creative Countryside: Policy and Practice in the UK Rural Cultural Economy." Journal of Rural Studies 26 (3): 209-218.

Burns, Jo, and Colin Kirkpatrick. 2008. "Creative Industries in the Rural East Midlands." In Regional Study Report. Nottingham: Culture East Midlands.

CCIA (China Creative Industry Alliance). 2018. "China 
Creative Industry Alliance.” Accessed 13 February 2019. http://www.china2049.cc/

Central Statistics Office. 2007. Census of Population 2006: Volume 1: Population Classified by Area. Dublin: Stationary Office.

Chen, Xiaohua, and Xiaolin Zhang. 2008. "Sunan moshi bianqian xia de xiangcun zhuanxing." [Village Transformation under the Sunan Model.] Agricultural Economic Problems 8 (1): 21-25.

China Association for Science and Technology. 2018. "China Industrial Heritage Protection List (First Batch).” China Urban Planning Web. Accessed 11 December 2019. http://www.planning.org.cn/news/ view id $=8109 \&$ cid $=0$

China Association for Science and Technology. 2019. "China Industrial Heritage Protection List (Second Batch)." China Urban Planning Web. Accessed 11 December 2019. http://www.planning.org.cn/news/ view?id=9624

Christen, Kimberly. 2006. "Tracking Properness: Repackaging Culture in a Remote Australian Town.” Cultural Anthropology 21 (3): 416-446.

Collins, Patrick, and James A. Cunningham. 2017. Creative Economies in Peripheral Regions. Springer.

Cui, Kai. 2018. "Jinxi Zhujiadian Brick Factory Renovation / Cui Wei Local Design and Research Center." Accessed Februrary 9 2019. https://www.archdaily.cn/ cn/886544/jin-xi-zhu-jia-dian-dian-zhuan-han-gaizao-cui-kai-star-ben-tu-she-ji-yan-jiu-zhong-xin

DCMS (Department of Culture Media and Sport). 2001. Creative Industries Mapping Document. London.

Florida, Richard. 2002. The Rise of the Creative Class: And How It's Transforming Work, Leisure, Community, and Everyday Life. Basic Books.

Florida, Richard. 2005. Cities and the Creative Class. Routledge.

Gaetano, Arianne M, and Tamara Jacka. 2004. On the Move: Women and Rural-to-Urban migration in Contemporary China. New York: Columbia University Press.

Gibson, Chris. 2014a. Creativity in Peripheral Places: Redefining the Creative Industries. 1st ed. Routledge.

Gibson, Chris. 2014b. "Introduction-Creative Geographies: Tales from the 'Margins'" In Creativity in Peripheral Places: Redefining the Creative Industries, 1 st ed,edited by Chris Gibson, 1-10. Routledge.

Gibson, Chris, and John Connell. 2004. "Cultural Industry Production in Remote Places: Indigenous Popular Music in Australia." In Cultural Industries and the
Production of Culture, edited by Dominic Power and Allen J Scott, 243-258. Routledge.

$\mathrm{Gu}$, Xin. 2011. "The Art of Re-industrialisation in Shanghai." Culture Unbound: Journal of Current Cultural Research 4 (1): 193-211.

Hee, Limin, Thomas Schroepfer, Su Nanxi, and Li Ze. 2008. "From Post-Industrial Landscape to Creative Precincts: Emergent Spaces in Chinese Cities.” International Development Planning Review 30 (3): 249-266.

Hesmondhalgh, David. 2013. The Cultural Industries. SAGE.

Higgs, Peter, and Stuart Cunningham. 2008. "Creative Industries Mapping: Where have We Come from and Where are We Going?" Creative Industries Journal 1 (1): 7-30.

Howkins, John. 2002. The Creative Economy: How People Make Money from Ideas. London: Penguin.

Jiang, Chunhai. 2002. "Zhongguo xiangzhen qiye fazhan lishi huigu." [Historical Review of the Development of Township Enterprises in China. Research on Township Enterprises.] Research on Township Enterprises 1 (2): 9-12.

KEA European Affairs. 2006. The Economy of Culture in Europe. Brussels: European Commission.

Kong, Lily, and Justin O'Connor, eds. 2009. Creative Economies, Creative Cities: Asian-European Perspectives. Dordrecht: Springer.

Landry, Charles. 2008. The Creative City: A Toolkit for Urban Innovators. 2nd ed. London: Earthscan.

Landry, Charles, and Franco Bianchini. 1995. The Creative City. London: Demos.

Lin, Yifu. 2003. “'Sannong' wenti yu woguo nongcun de weilai fazhan." [The 'Rural, Agricultural and Farmer's Problems' and the Rural Development in the Future.] Problems of Agricultural Economy 2003 (1): 19-24.

Liu, Yansui, and Yu Liu. 2010. "Zhongguo nongcun kongxinhua wenti yanjiu de jinzhan yu zhanwang." [Progress and Prospects of China's Rural Hollowing Research.] Geography Research 29 (1): 35-42.

Markusen, Ann. 2014. "Creative cities: A 10-year Research Agenda." Journal of Urban Affairs 36 (sup2): 567-589.

Markusen, Ann, and Greg Schrock. 2006. “The Artistic Dividend: Urban Artistic Specialisation and Economic Development Implications." Urban Studies 43 (10): 1661-1686.

McGranahan, David, and Timothy Wojan. 2007. "Recasting the Creative Class to Examine Growth Processes in Rural and Urban Counties.” Regional Studies 41 (2): 197-216. 
MOMA. 2019. "Design for Country." Accessed 9 February 2019. http://www.designforcountry.com/

Myers, Fred R. 2002. Painting Culture: The Making of an Aboriginal High Art. Durham: Duke University Press.

National Statistics Bureau. 2004. Classification of Cultural and Related Industries 2004. Beijing: National Statistics Bureau.

National Statistics Bureau. 2018. Classification of Cultural and Related Industries 2018. Beijing: National Statistics Bureau.

NESTA. 2006. Creating Growth: How the UK can Develop World Class Creative Businesses, NESTA Research Report. London: NESTA.

O'Connor, Justin, and Xin Gu. 2014. "Creative Industry Clusters in Shanghai: A Success Story?” International Journal of Cultural Policy 20 (1): 1-20.

OECD. 2014. "OECD Forum 2014: The Creative Economy." Accessed 5 February 2019. http://www.oecd.org/ forum/programme/sessions/thecreativeeconomy/

Oyekunle, Oluwayemisi Adebola Abisuga, and Mziwoxolo Sirayi. 2018. "The Role of Creative Industries as a Driver for a Sustainable Economy: A Case of South Africa." Creative Industries Journal 11 (3): 225-244.

Que, Weimin. 2007. "Guoji gongye yichan de baohu yu guanli." [On International Protection and Research of Industrial Property.] Acta Scientiarum Naturalium Universitatis Pekinensis 43 (4): 523-534.

Regional Technology Strategies Inc. 2003. "Clusters of Creativity: Innovation and Growth in Montana, A Report to the Montana Governor's Office of Economic Opportunity on The Creative Enterprise Cluster." Carrboro: Regional Technology Strategies Inc.

Regional Technology Strategies Inc. 2007. "Creativity in the Natural State: Growing Arkansas' Creative Economy." Carrboro: Regional Technology Strategies Inc.

Rosenzweig, Jacob, Patrick Roche, Faisal Chishty, Amy Thompson, and Faizan Ahmad. 2018. "How Governments Are Sparking Growth in Creative Industries.” Accessed 21 February 2019. https://www.bcg.com/ publications/2018/how-governments-are-sparkinggrowth-creative-industries.aspx

Sorensen, Tony. 2008. "Creativity in Rural Development: An Australian Response to Florida (Or A View from the Fringe)." International Journal of Foresight Innovation Policy 5 (1-3): 24-43.

State Administration of Cultural Heritage. 2006. "Notice on Strengthening Industrial Heritage Protection."

State Council of China. 2014. "Several Opinions on Promoting the Development of Cultural Creativity and
Design Services and Related Industries.” Beijing: State Council of China.

State Council of China. 2016. "Guideline on Emerging Sectors of Strategic Importance during the 13th FiveYear Plan Period (2016-20)." Beijing: State Council of China.

State Council of China. 2018. "Strategic Plan for Rural Revitalization (2018-2022)." Beijing: State Council of China.

State Council of China. 2019. "Guidance on Promoting the Revitalization of Rural Industries.” Beijing: State Council of China.

Stolarick, Kevin M, Mark Denstedt, Betsy Donald, and Gregory M Spencer. 2011. "Creativity, Tourism and Economic Development in a Rural Context: The Case of Prince Edward County." Journal of Rural Community Development 5 (1): 238-254.

Throsby, David. 2008. “The Concentric Circles Model of the Cultural Industries." Cultural Trends 17 (3): 147164.

TICCIH. 2003. Nizhny Tagil Charter for the Industrial Heritage. Nizhny Tagil.

Townsend, Leanne, Claire Wallace, Gorry Fairhurst, and Alistair Anderson. 2016. "Broadband and the Creative Industries in Rural Scotland." Journal of Rural Studies 54 (2017): 451-458.

Verdini, Giulio, Yiwen Wang, and Xiaonan Zhang. 2016. Urban China's Rural Fringe: Actors, Dimensions and Management Challenges. Routledge.

Vergara, René I. Castro, and Percy S. Marquina Feldman. 2018. "Impact of Broadband Uses on Labour Demand Derived from the Innovative Behaviour of Firms in Creative Industries." Creative Industries Journal 11 (3): 278-305.

Wang, Jing. 2003. "Framing Policy Research on Chinese 'Culture Industry': Cultural Goods, Market-State Relations, and the International Free Trade Regime." Workshop on Critical Policy Studies, Cambridge, MA.

Wang, Yi-Wen, and Xiangyi Wang. 2018. "Industrial Heritage Valorisation and Creative Industry Proliferation in Shanghai's Urban Regeneration." Built Heritage 2 (2): 76-92.

Wang, Yiwen. 2016. "Rural Regeneration in the Yangtze River Delta: The Challenge and Potential for Rural Heritage Tourism Development." In Urban China's Rural Fringe: Actors, Dimensions and Management Challenges, edited by Giulio Verdini, Yiwen Wang and Xiaonan Zhang, 111-144. Routledge Abingdon, UK. WDC (Western Development Commission). 2009. 
Creative West: The Creative Sector in the Western Region. Ballaghaderreen: WDC.

White, Andrew, and Sujing Xu. 2012. "A Critique of China's Cultural Policy and the Development of Its Cultural and Creative Industries: The Case of Shanghai." Cultural Trends 21 (3): 249-257.

White, Pauline. 2010. "Creative Industries in a Rural Region: Creative West: The Creative Sector in the Western Region of Ireland." Creative Industries Journal 3 (1): 79-88.

Williams, Raymond. 1975. The Country and the City. Oxford University Press.

Wu, Jiafei. 2007. "Qianxi Zhongguo xiangzhen qiye xianzhuang ji fazhan." [Analysis of the Current Situation and Development of Chinese Township Enterprises.] Economic Issues 1 (7): 58-59.

Xi, Jinping. 2013. Chinese Central Government's Urbanization Work Conference.

Xiang, Hardy Yong, and Patricia Ann Walker. 2013. China Cultural and Creative Industries Reports 2013. Springer.

Xiong, Chengyu, and Yan Fu. 2012. "Guanyu dangqian woguo wenhua chanye fenlei biaozhun de yanjiu." [Research on the Current Classification of China's Cultural Industries.] Social Science Front 1 (1): 149-155.

$\mathrm{Xu}$, Subin, and Nobuo Aoki. 2018. "Introduction to a Major Project of the National Social Science Fund: Research on China's Industrial Heritage Conservation System." Built Heritage 2 (1): 3-18.

Ye, Yingzhou, and Shuangyan Li. 2007. "Guoneiwai gongye yichan baohu yu zailiyong jingyan jiqi jiejian." [The Experience and Model of the Conservation and Reuse of Industrial Heritage Home and Abroad.] Shanghai Urban Planning Review 74 (3): 50-53.

Young, Craig. 2013. "The Migration Dynamics of the 'Creative Class': Evidence from a Study of Artists in Stockholm, Sweden." Annals of the Association of American Geographers 103 (1): 195-210.

Zhong, Sheng. 2009. "From Fabrics to Fine Arts: Urban Restructuring and the Formation of an Art District in Shanghai." Critical planning 16: 118-137.

Zhong, Sheng. 2010. "Industrial Restructuring and the Formation of Creative Industry Clusters: The Case of Shanghai's Inner City." PhD diss., University of British Columbia.

Zhang, Xiaoming. 2006. "From Institution to Industry: Reforms in Cultural Institutions in China." International Journal of Cultural Studies 9 (3): 297-306. 